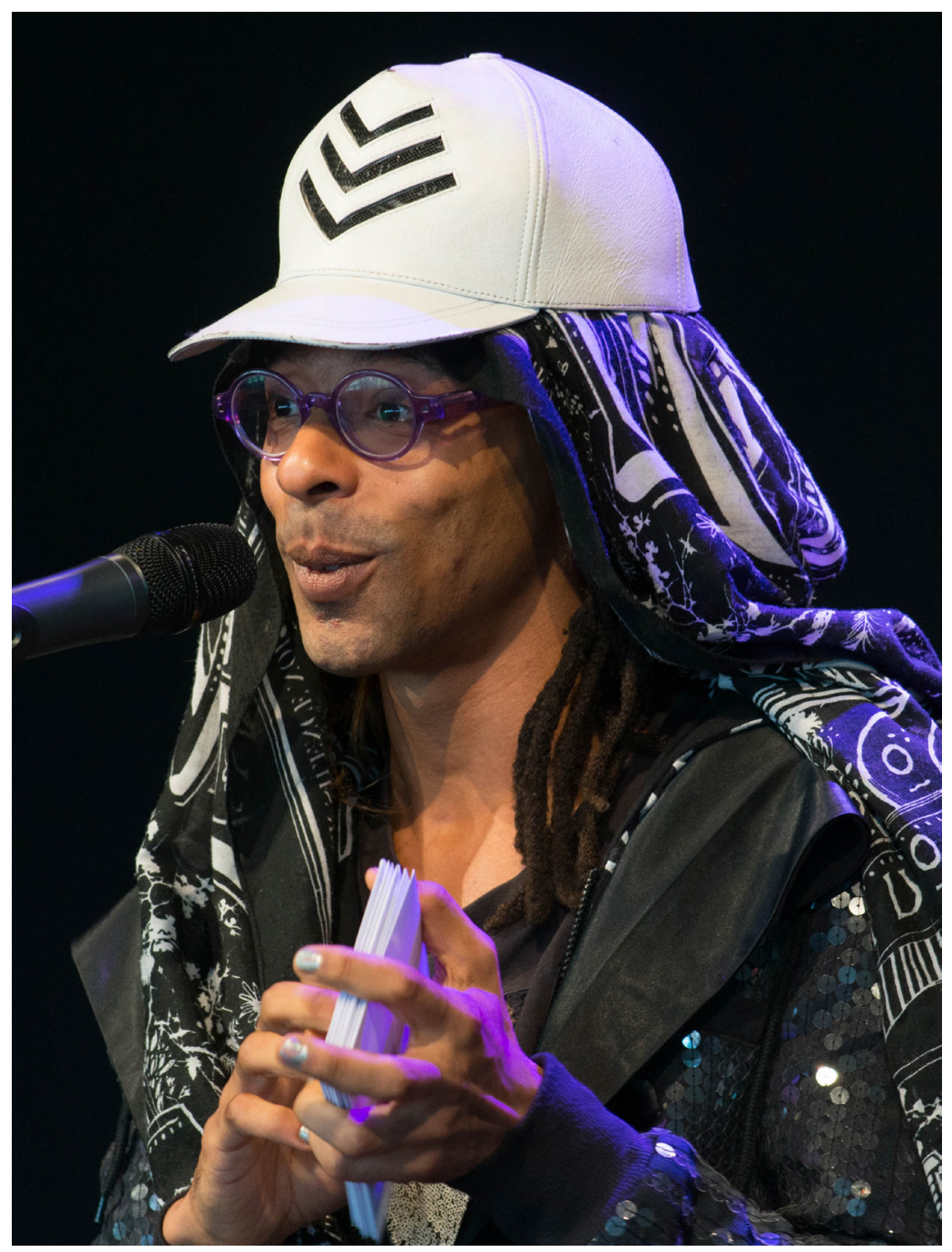

Makode Linde at a demonstration in support of endangered artists and writers at the Kulturhuset City Theatre in Stockholm, I 4 February, 20I 5. Photographer: Frankie Fouganthin. Copyright Creative Commons Attribution-Share Alike 4.o International license, CC-BY-SA. https:// sv.wikipedia.org/wiki/Makode_Linde\#/media/File:Makode_Linde_in_ Feb_20I5.jpg 


\section{Against Tolerance: Thoughts on Contemporary Scandinavian Racism}

Over the last few decades, traditionally "tolerant" northern Europe has witnessed the rise of populist and neo-fascist movements. These have resulted in political parties such as the Finns (Perussuomalaiset), the Danish People's Party (Dansk Folkeparti), the Sweden Democrats (Sverigedemokraterna), and the Norwegian Progressive Party (Fremskrittspartiet). Such factions have effectively interpreted the ongoing economic situation as a "national identity crisis." It is as if politicians had nothing to offer people other than a national identity, rather than engaging in a political analysis of the decline of the Nordic welfare state.

The emergent right-wing parties have cultivated troubling thoughts about an unambiguous, monolithic national culture and history. These fantasies of "pure" nations cleansed of immigrants echo Europe's darkest past and recirculate nationalism as a model for the future in many European countries. In 2010, German Chancellor Angela Merkel gave a historic speech whose essence may be summed up in a few words: "Multikulti ist absolut gescheitert" (Multiculturalism has absolutely failed). Merkel, perhaps the most powerful politician in Europe, was not the only one declaring that multiculturalism in Europe was dead. Nicholas Sarkozy, the French president at the time, along with British Prime Minister David Cameron both shared Merkel's view.

According to them, multiculturalism gives rise to violence. Merkel emphasized the word Leitkultur, a national core culture. Sarkozy, himself a descendant of Hungarian immigrants, conjured up a threat to French culture, and Cameron spoke of muscular liberalism. All three agreed that the Achilles heel of multiculturalism

How to cite this book chapter:

Rosenberg, Tiina 20I6. Against Tolerance: Thoughts on Contemporary Scandinavian Racism. In: Rosenberg, Tiina Don't Be Quiet, Start a Riot! Essays on Feminism and Performance. Pp. 206-217. Stockholm: Stockholm University Press. DOI: http://dx.doi.org/IO.I6993/baf.k. License: CC-BY 4.0 
is the Muslim population in Europe. This discourse creates an imaginary national virginity, which gives people a sense that they belong to a single collective "we." Michael Warner calls processes of these types appellative energy based on a loss of social memory and willful ignorance of inequality and marginalization. ${ }^{\mathrm{I}}$

In Inszenierte Wirklichkeit, Joachim Fiebach investigates global cultural performance as theatrical and symbolic acts. Inspired by Victor Turner, Fiebach sees symbols as social processes whereby groups become adjusted to internal changes and adapt to their external environment. ${ }^{2}$ The Nordic countries are used to holding themselves out as prime examples of the welfare state, and will eagerly admonish others in this regard. Jasbir K. Puar labels this phenomenon exceptionalism that "paradoxically signals distinction from (to be unlike, dissimilar) as well as excellence (imminence, superiority), suggesting the departure from (yet mastery of) linear teleologies of progress." 'Scandinavian exceptionalism means that "we" have things under control, while the rest of the world is still busy fighting inequality. Fiebach emphasizes the power of the symbolic and of the mythical. Two recent events, Tintin in the Congo and the Cake Scandal, are performative examples of these phenomena.

\section{Tintin in the Congo}

In 2012 a heated debate about structural racism took place in Sweden when Behrang Miri, the artistic director of the children's division of the Stockholm Culture Center (Kulturhuset), removed the comic book Tintin in the Congo from the reading room. He said he acted because of the racist and colonialist descriptions of the African, Turkish, and Russian characters in the book. Others conjectured that if children's literature were to be analyzed from a post-colonial, anti-racist perspective, not many books would be left on public library shelves. Civil conversation on this topic quickly turned into heated exchanges and hate speech in social media with calls to "Remove Behrang Miri!" It was a classic whistler blower scenario in which the message is lost and vituperation is directed at the messenger - in this case someone who had wanted to make a point about a valid social issue.

Tintin comics have come under criticism for a long time. Their author, cartoonist Georges Remi (pen-name Hergé), has been 
denounced in his home country of Belgium for his Nazi sympathies. A trial against Tintin in the Congo took place there in 20I I, but the outcome was inconclusive. It was argued that since the book was written in I93 I, the author could not help adopting the racial stereotypes of the time. In Sweden the book's publisher, Bonnier Carlsén, was similarly charged in 2007 . There have been other controversies about recent children's literature. Even Ingrid Vang Nyman's classic drawings for Astrid Lindgren's Pippi Longstocking in the South Pacific (Pippi i Söderhavet) have been criticized, as was the content of the book, in which Pippi's father is the "negro king" of the mysterious Kurrekurredutt Island. The list goes on and includes many classics of children's literature. ${ }^{4}$

The cry of racism in bitter media debates is often cited as the irrational attitude of a disturbed individual. Nevertheless, postcolonial scholarship has shown that racialized stereotypes are structurally produced and perpetuate racism. Stereotypes recycle a particular iconography of otherness, seeking to explain diverse everyday experiences by very simple means. The debate over Tintin inevitably raises the question of how people transmit stereotypes of those they do not know, homogenizing otherness into a single entity in their skewed descriptions of human beings.

Postcolonial studies examine power structures related to colonialism, imperialism, and racism. Ever since the seventeenth century, Europeans have exploited other nations. Even the Nordic countries, although often disclaiming colonialism, have had a colonial past. Compared to the UK, France, and Portugal the history of Nordic colonialism may seem modest, but one should remember the very tenuous Nordic critique of Nazism in the World War II era. To this day discrimination continues in Scandinavia against the Roma and Sami people. One should also not forget the Swedish State Institute for Racial Biology (Rasbiologiska Institutet) in Uppsala, which only closed in 1958 , and other institutions based on race, ethnicity, or colonialism in the Nordic countries.

At its core, racism has a structure that relies on fabrications to categorize otherness. It produces a metaphorical darkness whose paradigmatic expression has been found it Joseph Conrad's Heart of Darkness. Although Conrad's darkness was existential and went deeper than a literal reading of black Africa, its setting was the same colonial landscape in which Tintin's adventures took 
place. This symbolic Congo, and beyond it the whole of Africa, is considered a place of otherness, legitimizing the exploitation of Africa and keeping it the "dark" continent.

\section{The Cake Scandal}

At the same time that Tintin in the Congo was being debated, another race-related cultural event took place in Sweden, the so-called Cake Scandal, also referred to as Cakegate, in homage to Watergate. It began as an installation by the artist Makode Linde, who created an actual cake in a shape of an African woman wearing a blackface mask. The occasion was a celebration of World Art Day at the Museum of Modern Art in Stockholm. The cake was part of Linde's Afromantics, a work that examined Western stereotypes of contemporary Africa and Africans.

At the reception, the edible creation was offered to the Swedish Minister of Culture, Eva Adelsohn Liljeroth, and representatives of other cultural organizations. Liljeroth cut the first piece, not realizing the symbolism of what she was doing. The distinguished guests were unnerved as the cake "woman" screamed whenever a piece was cut off. As it turned out, behind the blackface was the artist himself. Photos and videos of the event circulated widely, showing white people laughing and enjoying themselves as they dismembered the portentous black body. The consequence was a huge cultural debacle. ${ }^{5}$ In the midst of it all, Linde declared that the artist's responsibility is to experiment.

If we wish, there can be a wide spectrum of representations of blackness in Swedish culture. Artists should be allowed to experiment with colors, figures, forms, expressions, and meanings. The power of art is in its ability to turn our ideas and concepts upside down and invest old symbols with new meanings. ${ }^{6}$

Art and popular culture capture our contemporary moment, along with its problems and delights. But art in itself is an ideologically charged ritual, since everything has a history and a context, and we all stand on the shoulders of others. Sweden's Minister of Culture was acting in the presence of countless ghosts of the colonial past, and generations of invisible African ancestors who 
metaphorically winced each time the knife bore down. The inevitable question was whether someone so naïve as to take part in such a ceremony was the right person to serve as Sweden's cultural minister. Was Liljeroth blind to the connection between white people nonchalantly cutting off pieces of a black marzipan body, and all the black bodies that have been violated in countless acts of brutality down through the centuries?

In I955, Aimé Césare wrote a critical analysis of colonialism, Discours sur le colonialisme, in which he discusses different types of racism. ${ }^{7}$ Césaire points out that there is a tendency to view European manifestations of evil as accidental events of some kind. It is as if European racism were a reminder of some barbarous, long-forgotten past whose memory may suddenly rekindle the sacrificial fires. He describes how the French bourgeoisie reacted to Nazism during the World War II. According to Césaire, they did not oppose anti-Semitism because the Nazi invaders were too close at hand and were threatening their own lives. They also looked the other way when it came to the racism suffered by Africans, Asians, and indigenous people, since those inequities were directed at people who were geographically far removed from France, and therefore difficult to identify with.

After the Cake Scandal, the author and literary critic Stefan Jonsson commented that what the artist had shown was that the white woman who cut a piece of a black woman was, in fact, just a white woman who cut a piece of a black woman. "And all of a sudden we see it. White people cut black people. Our Minister of Culture participates in it, and this is part of the order of things, still a natural part of the order in which white people are laughing while cutting up the fake body of a black woman." ${ }^{8}$

\section{Against tolerance}

Europe has always been a complex and multi-cultural part of the world, but in recent decades it has become evident that European societies are unable to handle blatant, increasingly visible racism. At stake is a value-based conservatism, political populism, and neo-fascism. Behind Tintin and the Cake Scandal is the old but newly-recovered cultural biologism, or essentialism as it has been called, the 
idea of a genetically inherited repulsive culture that in Europe today encompasses all immigrants, but especially Muslims and Africans.

Democracy and human rights may be abstract concepts to some, but to others they are the concrete foundation of political activity. Democracy loses its power if it is turned against human rights and equality. The situation is problematic, as French philosopher Alain Badiou has said, because democracy is the self-appointed emblem of the West - a badge of honor. ${ }^{9}$ A democrat only respects another democrat. However, when non-Western immigrants are discussed, there is not much talk about democracy, humanism, or human rights. Instead, the discourse shifts to identity cards, national borders, refugee camps, and police raids. According to Badiou, the world is divided into the "good" democratic world, and the "bad" anti-democratic communities. While human interaction is rarely so simple, because of such bias one person's notion of the social hierarchy does not match another's.

Democratic and anti-democratic tendencies work side by side, and affect each other in different ways. If conservative and nationalist ideas form social practices, we can also think and act to the contrary. Democratic actions are implemented to create new and more equitable social practices. Minorities and corresponding majorities do not exist in a vacuum, but are socially and historically produced. Social boundaries create minorities and vice-versa. The majority of the population has the power to define what culture, democracy, and the nation are about, and can make a variety of legislative proposals in the name of tolerance.

Feminist theorist Wendy Brown has stated that tolerance is based on the concept of aversion towards the tolerated ones. ${ }^{\text {Io }}$ As a concept, tolerance contains within it the power to tolerate or fail to tolerate an individual or a community. The cultural biologism that underpins racism defines those people who are considered obnoxious, and those communities who cling to their identity and resist becoming like the majority. As a result, the active social presence of minorities - especially unwanted migrants - is perceived as a threat to the nation.

For decades cultural studies and critical theory have insisted that culture is constantly in a state of change. Its boundaries are not permanent, and so national culture can never be precisely defined. 
Culture has always been a construction, just as much as politics and the writing of history. It is something produced by people themselves and for that reason should be analyzed as an ideological, not an essentialist, phenomenon. Social ills cannot be defined or justified by biologism or genes, or even less by a Leitkultur.

Fiebach points out that it is impossible to overestimate the change in global politics that followed the September I I attacks in New York in 200I. ${ }^{\text {I }}$ The subsequent "war on terror " introduced a new political climate. Muslim countries were no longer orientalist cultures, but acute threats to the West. In the post-9/I I world mistrust has spread far beyond populist and neo-fascist parties and communities. Immigrants and radicalized extremists have now become the major political challenge to Europe.

Those who have analyzed the period after the 200I attacks agree that both politics and theory changed at the time. Samuel P. Huntington's Clash of Civilizations declared in 1996 that the ideological struggle of the Cold War was over. ${ }^{\mathrm{I}}$ Future conflicts would now be between different civilizations, and the struggles would be cultural. Huntington emphasized the relationship between Muslims and non-Muslims. He wished to introduce a new reading of history, claiming that Islam has always threatened the West. The pages of Western history are filled with descriptions of bloody clashes against Muslims. Huntington's historiographical point of departure was the West's “eternal struggle" against Islam, coupled with the Eurabia conspiracy theory that Muslims are invading the West through immigration.

\section{Affect economy}

In order to understand the emotional debates over Tintin in the Congo, the Cake Scandal, Angela Merkel's desire to strengthen German core culture, growing political populism, and neo-fascism in Europe, one must be aware of the affects involved. Sara Ahmed writes about affect economy and views contemporary social boundaries from an intersectional perspective. Thus, social phenomena such as gender and race do not create meaning by themselves, but always in combination with location, time, and context. Affect economy is not primarily a matter of personal 
experience or individual emotions. It encompasses the entire spectrum from love to hate. The way to the hearts of people traverses affects: put simply, what "feels" right, is right. ${ }^{\mathrm{I3}}$

Looking upon so-called authentic feelings as suspect is not a new idea, but a classic attitude of critical theory. Ahmed connects feminist, postcolonial, and queer critique, focusing on the question of how socially defined intersections change and develop through various encounters, emotions, and bodily interactions. Mobility between nations depends upon the affect economy creating an order that allows certain privileged people to move freely from one place or country to another, while others are unable to do so. Borders cannot simply be crossed by anyone at any time. Ahmed reminds us that not all tourists, immigrants, or foreigners are defined as guests or strangers, as the case may be. Many of them are more "at home" than others and are not asked questions about their family's national origin. Even holding the "right" passport will not help in a situation where one has the "wrong" name or skin color.

\section{Ruined self-image}

Sometimes what looks on the surface like a meeting is actually an encounter with one's own mirror image. If one looks at the Tintin and Cake affairs and the controversy surrounding them, it appears that media debates have become a ritual. The purpose of the debates was not to come up with new insights or interpretations, but to use the "others" as a tool with which to strengthen the national community.

One needs an external enemy who can validate the raison d'être of one's own group. It is a human all-too-human behavior, but problematic nevertheless. The attempt at censoring Tintin in the Congo and the entrapment of the Cake Scandal were exploited by the media to show the madness of trying to say something about structural racism. The events functioned as occasions to trigger ritualized actions that might secure national identity, rather than promote a meaningful exchange of ideas.

Both Tintin in the Congo and the Cake Scandal exposed the cluelessness of the insiders as well as the dangers to outsiders. While people fumed over the attempt to censor Tintin, and literature in general, the cultural elite saw their self-image ruined in the 
Cake Scandal: 'We are good people with good values. No one has been hurt!' the noble self-image proclaims. 'We like diversity!' although their practice tells otherwise. In the end both events were about superiority and inferiority. Fiebach states that one possible way out of the dilemma is to consider how strongly and in what ways "symbolic bodies" manifest themselves in the most varied non-media public spaces, beginning with the street and extending to open or closed meeting rooms - how they are present there, and how they experience, suffer, and treat the world there. ${ }^{\mathrm{I}}$ Alternative spaces and alternative ways of expressing oneself have always offered breathing room for artists. In those spaces the ideas of Behrang Miri and Makode Linde might make sense after all. Thus, Tintin in the Congo and the Cake Scandal can be seen as welcome contributions that provoked eye-opening revelations into the majority's crueler side. Few horror movies are as scary.

\section{Notes}

I. Warner, Publics and Counterpublics, 89. See also Anderson, Spectre of Comparisons and, by the same author, Imagined Communities.

2. Fiebach, Inszenierte Wirklichkeit, 2 I.

3. Puar, Terrorist Assemblages, 3.

4. Habel, Ylva: "Den svenska vithetens blinda fläck"; Jensen, "Kom inte här och kom"; Mellgren, "Kort bannlysing av Tintin”; Söderling, "Tintin bannlyst på Kulturhuset" and, by the same author, "Nu får barnen läsa Tintin igen” and "Lilla Hjärtat kvar på biblioteket."

5. Barkman, "Krav på avgång”; Helgesson \& Ekman, "Motsägelsefull och meningslös”; Hjort, Svanell, \& Loman, “Avgångskrav efter tårtkalas"; Kempe, "Rastänkandet effektivt punkterat”; Loman \& Hjort, "Nu står gallerierna på kö"; Monnakgotia, "Afrosvenskarna delvalverar ordet rasism”; Neuman, “Makode slår till igen”; Schottenius, “Makode Linde.”

6. Linde, "Tusen nyanser av svart."

7. Césaire, Discours.

8. Jonsson, "När de vita skär i den svarta tårtan."

9. Badiou, "L'emblème démocratique." 
Io. Brown, Regulating Aversion.

I I. Fiebach: Inszenierte Wirklichkeit, Iо-I I.

I 2. Huntington, Clash of Civilizations?

I3. Ahmed, "Affective Economies."

I4. Fiebach: Inszenierte Wirklichkeit, 285.

\section{Works Cited}

Ahmed, Sara. “Affective Economies.” Social Text 22 (2004): I I 7-I39.

Anderson, Benedict. Imagined Communities. Reflections on the Origin and Spread of Nationalism. London: Verso, 2006.

- The Spectre of Comparisons. Nationalism, South East Asia, and the World. London: Verso 1998.

Badiou, Alain. “L'emblème démocratique.” In Démocratie dans quel état?, edited by Giorgio Agamben, Alain Badiou, Daniel Bensaïd, et al., I9-27. Paris: Broché, 2009.

Barkman, Clas. "Krav på avgång efter tårtskandal” (Resignation Demanded after Cake Gate). Dagens Nyheter, I 8 Apr 20 I 2.

Brown, Wendy. Regulating Aversion: Tolerance in the Age of Identity and Empire. Princeton, NJ: Princeton University Press, 2006.

Césaire, Aimé. Discours sur le colonialisme. Paris: Éditions Présence Africaine, I955.

Fiebach, Joachim. Inszenierte Wirklichkeit. Kapitel einer Kulturgeschichte des Theatralen. Berlin: Theater der Zeit, 2007.

Habel, Ylva. "Den svenska vithetens blinda fläck" (The Blind Spot of Swedish Whiteness). Svenska Dagbladet, I 2 Sept 20 I 2.

Helgesson, Stefan, and Kajsa Ekis Ekman. "Motsägelsefull och meningslös. Rasism är inte en fråga om gester och utseende" (Contradictory and Meaningless: Racism is Not a Matter of Gestures and Appearance). Dagens Nybeter, 25 Apr 2012.

Hjort, Mira, Adam Svanell, and Stina Loman. "Avgångskrav efter tårtkalas" (Resignation demanded after Cake Gate). Svenska Dagbladet, I 8 Apr 2012. 
Huntington, Samuel P., ed. Clash of Civilizations? The Debate. New York: Foreign Affairs, I996.

Jensen, Emil. “Kom inte här och kom” (Don’t Come Here to Provoke!). ETC Stockholm, 5 Oct $20 \mathrm{I} 2$.

Jonsson, Stefan. "När de vita skär i den svarta tårtan” (When Whites Slice into the Black Cake). Dagens Nyheter, 22 Apr 2012.

Kempe, Jessica. "Rastänkandet effektivt punkterat" (Racism Effectively Punctuated). Dagens Nyheter, I 2 May 20 I 2.

Linde, Makode. "Tusen nyanser av svart" (A Thousand Shades of Black). Dagens Nybeter, 28 Sept 2012.

Loman, Stina, and Mira Hjort. "Nu står gallerierna på kö" (The Galleries are Lining Up). Svenska Dagbladet, I9 Apr 2012.

Mellgren, Fredrik. "Kort bannlysing av Tintin" (A Brief Ban on Tintin). Svenska Dagbladet, 26 Sept 2012.

Monnakgotia, Tebago. "Afrosvenskarna delvalverar ordet rasism" (African Swedes Devalue the Word Racism). Dagens Nyheter, 24 Apr 20I2.

Neuman, Ricki. "Makode slår till igen - i Kungsträdgården" (Makode Strikes Back - in Kungsträdgården). Svenska Dagbladet, 8 Jun 2012.

Puar, Jasbir K. Terrorist Assemblages: Homonationalism in Queer Times. Durham, NC: Duke University Press, 2007.

Schottenius, Maria. "Makode Linde är nominerad till DN:s kulturpris" (Makode Linde is Nominated for the DN Cultural Award). Dagens Nybeter, 3 I Jan 2012.

Söderling, Fredrik. “Tintin bannlyst på Kulturhuset” (Tintin Banned by Kulturhuset). Dagens Nyheter, 25 Sept 2012.

- "Nu får barnen läsa Tintin igen" (Now Children a
Allowed to Read Tintin Again). Dagens Nyheter, 26 Sept 2012.

—_. "Lilla Hjärtat kvar på biblioteket" (The Little Heart is Still in the Library). Dagens Nyheter, 23 Nov 2012.

Warner, Michael. Publics and Counterpublics. New York: Zone Books, 2005. 